\title{
Muslim-American Marketplace: Understanding Cultural Diversity
}

Nadia Abgrab Noormohamed, (Email: nadia.abgrab@salve.edu), Salve Regina University

\begin{abstract}
The Muslim-American marketplace is a cultural challenge for US businesses offering numerous generational interpretations of each nationality, traditions, and historical values.
\end{abstract}

\section{INTRODUCTION}

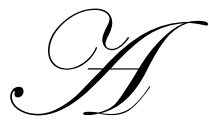

mericans who practice the Islamic faith enrich our society and help our Nation build a better future. American history has taught us to welcome the contributions of men and women of all faiths, for we share the fundamental values of religious freedom, love of family, and gratitude to God." President George W. Bush spoke these poignant words on October 15, 2004 as Muslims begin to observe Ramadan (a name of a month in the Muslim calendar), the holiest season in their faith commemorating the revelation of the Qur'an to Muhammed. With the majority of Muslim-Americans highly educated (90\% have some education) and 66\% registered to vote in the United States (Soliman) - one quarter of them living in New York City (Sheikh); this compassion extended by the President to commitment and social justice will find new ways to reflect the richness of the American consumer's imagination. (Morais)

One of President Bush's closest advisers, Karen Hughes - United States Under Secretary of State for Public Diplomacy, told a gathering of American Muslims that part of her new State Department job was, "to help amplify the voices of groups like theirs... and to foster a sense of common interest and common values among Americans and people of different faiths and different cultures", basically to Educate America! These views were also reiterated by the National Endowment for Democracy. As reported by David Yonke, the Toledo Blade religious editor, Muslims in America are immigrants who come from a broad range of Islamic nations. The Islamic Center of Greater Toledo, for example, has members from 23 different countries. Currently there are approximately 1.2 billion Muslims in the world, 7 million in the United States as represented in Table I by ethnic origin. There are more Indian Muslims than Arab Muslims, and more Indonesian Muslims than Indian Muslims. This huge market is virtually untapped and offers great potential and financial gains if properly targeted.

Islam has many faces and different ethnic identities, yet little is know about Muslim-Americans. Islam is a faith that celebrates peace and honors diversity, and values knowledge and understanding as a fundamental principle of both spiritual and secular lives. American Muslims represent a rich mosaic of ethnic, racial, linguistic, tribal and national identities that stretch from the Middle East to South Asia to Africa and beyond. (Afridi) One of the most common misconceptions or stereotypes Westerners have about Muslims is that most of them are Arabic...Muslims are, by and large, people of color." (Shama) The Truth of Islam is meant for all people regardless of race, nationality or linguistic background. Taking a look at the Muslim world, is enough to prove that Islam is a Universal message for all of mankind -- not to mention the fact that significant numbers of Americans of all races and ethnic backgrounds are coming into Islam. (islamnet.com) 


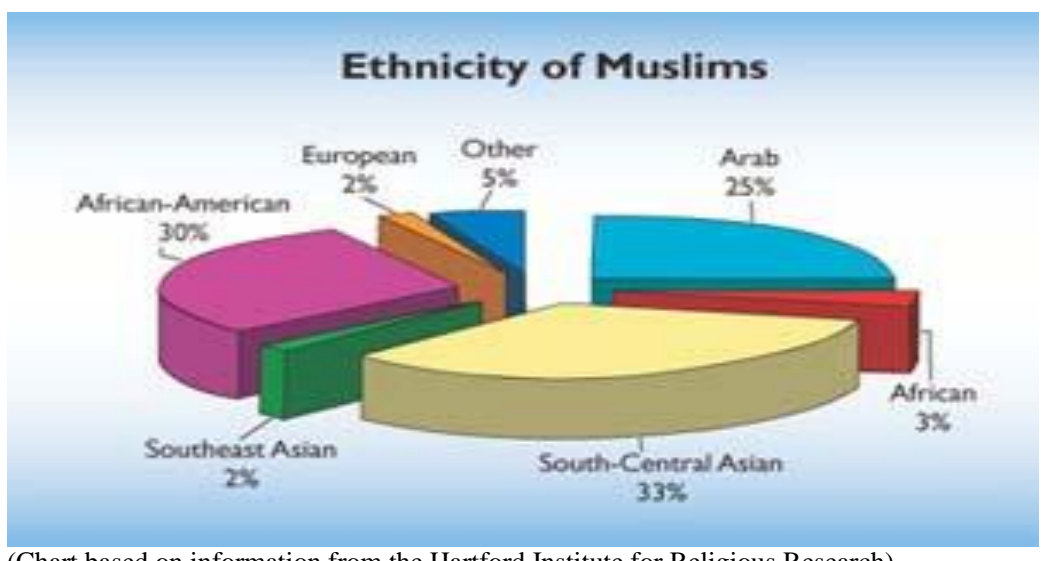

(Chart based on information from the Hartford Institute for Religious Research)

Table I: U.S. Muslim Population

\begin{tabular}{|c|c|c|}
\hline $\begin{array}{c}\text { Ethnic } \\
\text { Grouping }\end{array}$ & $\begin{array}{l}\text { Percent of } \\
\text { Total } \\
\text { Muslim } \\
\text { Population }\end{array}$ & Definition of Terms \\
\hline $\begin{array}{l}\text { South } \\
\text { Asians }\end{array}$ & 33.0 & $\begin{array}{l}\text { South-Asians: Those of Indian, Pakistani, Sri Lanoka, Bangladeshi, or Afghani descent now } \\
\text { residing in the United States as citizens or permanent residents. }\end{array}$ \\
\hline $\begin{array}{l}\text { African- } \\
\text { American }\end{array}$ & 30.0 & African-Americans: Those persons of African descent native to the United States of America. \\
\hline Arabs & 25.0 & $\begin{array}{l}\text { Arabs: People from Arabic-speaking countries of the Middle East and North Africa who are } \\
\text { permanent residents or citizens of the United States. }\end{array}$ \\
\hline Africans & 3.0 & Africans: People from the African continent who are citizens or permanent residents of the US \\
\hline $\begin{array}{l}\text { Southeast } \\
\text { Asians }\end{array}$ & 2.0 & Southeast Asians: People of Thailand, Malaysia, Indonesia, Indochina, or the Philippines. \\
\hline Europeans & 2.0 & East Europeans: People from various regions of Eastern Europe: Bosnian, Tartar, Kosovar, etc \\
\hline Other & 5.0 & $\begin{array}{l}\text { Iranians: People of Persian descent, usually from Iran -who are citizens or permanent residents } \\
\text { Turkish: People of Turkish descent who are citizens or permanent residents. } \\
\text { American Whites: Those of West European descent, who are native to the United States. } \\
\text { Other: Hispanic/Latino, Caribbean, etc }\end{array}$ \\
\hline Totals & 100.0 & \\
\hline
\end{tabular}

Most Americans do not have a true understanding about Islam or Muslims. According to the Encarta Dictionary, Muslims are people who believe in, follow, and practice Islam. Islam is based upon the teachings of Muhammad during the $7^{\text {th }}$ century and is now the second largest of the great religions in number of believers. Although statistics are constantly changing, it is reported by the United States Department of State that Islam is the fastest growing religion in the United States (a non-Islamic country) and is on the verge of becoming the country's second largest religion by 2010 (Catholicism being the first). Most immigrants came to the United States in the 1960's-1970's and now make up the largest segment of the American Muslim community. The second largest group of American Muslims includes those who are now in their third an fourth generation as well as a large group of converts, the majority of whom are of African-American descent. Table II depicts the geographic distribution by states of the largest Muslim communities in the United States.

Native-born American Muslims are more openly accepting of immigrant Muslims and their culture than the latter are of them. For Islam to make sense in America, systemic predictability needs to evolve. We need a type of unity that will place the whole of the community on one spectrum. Currently, Muslim communities are demarcated 
primarily on the basis of race, ethnicity, and nationality all of which are ludicrous notions especially given the current attack that Islam is under. The irony of Islam in America is that except for a few instances, we are thoroughly integrated secularly and civilly, but grossly separated and dysfunctional religiously. (Ahmad)

Islam spans many different ethnicities and brings together numerous cultures to similar places. The common factor that bonds this group is their faith. It is not uncommon to observe a multiethnic population in prayer under one roof. Muslim-Americans are also working among us everyday. Professional sports figures, store owners/managers and salespersons, teachers, news media (of which there are few), lawyers, doctors, taxi drivers, and even politicians are all part of our daily lives - working in a Western world.

Farheen Hakeem, a 29-year-old Chicago native, is the 5th Congressional District Green Party endorsee for mayor of Minneapolis in 2005. She is formerly a math teacher turned Girl Scout membership coordinator for Muslim girls, an antiwar activist, stand-up comedian, and free-lance writer. Hakeem wears a hijab, the traditional Muslim headscarf, which she believes gives the impression to people who see it that she is submissive, soft-spoken and not proficient with the English language - none of which are true. Her spirit for diversity can be shared by her words, "I want our world, and our democracy, to be thriving and surviving. When I see representation of all people in Congress and the city level, then I know I can go back and teach math again." (Russell) Unfortunately, Farheen Hakeem lost with only 18 percent of the vote.

According to the biennial report issued by the American Muslim Alliance (AMA), more American Muslims have been elected to public office within this past year than in previous years despite the wave of Islamophobic attacks and stereotyping. There are four main trends: 1) steady gain for Muslim candidates, 2) highest-ever American Muslim voter turnout, 3) highest bloc vote percentage in the nation, and a 4) diversification of political affiliations. Most Muslim candidates ran as Democrats, while roughly 25 per cent ran as Republicans. Muslim candidates ran for a variety of offices at local, state and federal levels with the exception of the presidency and the governorships. A comparison of the performance of Muslim candidates in 2000, 2002, and 2004 offers the following: about 100 Muslims ran for various public offices in 2004, a modest improvement over less than 70 Muslim candidates in 2002 (10 candidates out of about 70 elected to various public offices which include 1 State Senator, 3 State Assemblymen and 1 judge of Superior Court), but still far less than the all-time high of 700 candidates in 2000. (Kira)

Table II: Muslim State Population

\begin{tabular}{|c|c|c|c|}
\hline \multicolumn{1}{|c|}{} & $\begin{array}{c}\text { Muslim Population } \\
\text { in 1000's } \\
\mathbf{( 1 9 9 0 )}\end{array}$ & $\begin{array}{c}\text { Percentage Total Muslim } \\
\text { Population }\end{array}$ & $\begin{array}{c}\text { Percent of Total State } \\
\text { Population }\end{array}$ \\
\hline State & 1,000 & 20.0 & 3.4 \\
\hline California & 800 & 16.0 & 4.7 \\
\hline Illinois & 420 & 8.4 & 3.6 \\
\hline New Jersey & 200 & 4.0 & 3.2 \\
\hline Indiana & 180 & 3.6 & 1.8 \\
\hline Michigan & 170 & 3.4 & 2.4 \\
\hline Virginia & 150 & 3.0 & 0.7 \\
\hline Texas & 140 & 2.8 & 1.2 \\
\hline Ohio & 130 & 2.6 & 1.4 \\
\hline Maryland & 70 & 1.4 & \\
\hline
\end{tabular}

Estimates under column 2 have been rounded to the nearest even number. 


\section{PROMOTING TO THE MUSLIM-AMERICAN MARKETPLACE}

Marketing to various international cultures (political, religious, and social) requires an understanding for the unique lifestyles and values of all Muslim-Americans. Integrating those values into American products and/or services to find commonality, while upholding the respect for national diversity, requires a delicate balance that will have a powerful impact on consumerism. "To win the hearts and minds of American Muslims, considerable economic and cultural contributions need to be incorporated into the mix. Marketers must develop an understanding for the Islamic heritage, traditions, and world - a long courtship to which Americans are unaccustomed. Whatever their faith, consumers all over the world have demonstrated similar desires and needs. American Muslims are looking for morally acceptable activities all with a common adherence to Islamic values - the safety net that keeps the family together." (Noormohamed)

One organization that appreciates the process of building a direct relationship with various international cultures of life is the National Islamic Committee on Scouting. Muslim scouts pursue special emblems by studying Islamic history and theology and performing faith-related community service, in addition to the merit badges that all scouts can earn in such areas as cooking and plumbing. There are now all-Muslim scout packs and troops in at least 22 states, involving more than 2,000 scouts and leaders, awarding approximately 75 to 80 emblems per year - in contrast to the 2 to 3 emblems awarded per year 15 years ago.

The challenge is for American marketers to better understand the Muslim way of life in order to be able to positively effect change in future buying behavior. Recently, Dina Habib Powell (a former White House personnel director), an Egyptian-born Arab American was unanimously confirmed by the Senate to serve as Assistant Secretary of State for Educational and Cultural Affairs on July 18, 2005. Arab American Institute President Dr. James in Washington, D.C. believes that her appointment uniquely qualifies her and is a step in the right direction to serve as a bridge between the United States and the Arab and Muslim world. Mrs. Powell graduated with honors from the University of Texas, Austin. Earlier in her career, she was the Director of Congressional Affairs for the Republican National Committee in Washington, D.C. and has also served as a member of House Majority Leader, Dick Armey's senior staff.

In an effort to reach the appropriate target audience, print media such as newspapers, direct mail, and magazines are distributed to the top ten cities listed in Table II as a cost-effective promotional tool. Technology now brings Al-Jazeera TV from Qatar to about 150,000 households with satellites in the United States, as well as CNN and MSNBC, directly into living rooms. (Ghannam)

Bridges TV, a new network (created by Muzzammil Hassan, who came to the United States from Pakistan in 1979), serves to build bridges between the diverse American-Muslim community and other Americans, debuted in December 2004 in a deal with Comcast. This first English-language network for Muslims focuses on lifestyles and entertainment in America and carries a broad range of programs including animated Koran stories, biographies, cartoons, current-event programs, daily news, educational shows, fashion, movies, sports, talk shows, and comedy. The viewing audience is an affluent (average household income \$54,000 US) and well-educated group that should be attractive to advertisers. (Parsons)

The Muslim community adds considerable strength to the economic environment. Several experts said the per-capita income for Muslims is between $\$ 38,000$ and $\$ 43,000$ a year, compared with a U.S. per-capita income of $\$ 22,200$, according to the U.S. Census Bureau. HSBC financial services says that 32 percent of American Muslim households make more than $\$ 75,000$ per year, yet fewer than one in 10 U.S. Muslims use Islamic-based services. Murabaha mortgages (enables buyer to pay a higher price for a property instead of paying interest) is one of the popular Islamic financial services recently launched by the bank with only 4 percent of Muslims taking advantage of shari'ah-compliant mortgages (Shariah law prohibits transactions which involve interest. It is considered unacceptable for money to increase in amount simply by it being lent to another individual. This rule prevents those abiding by Shariah law from using conventional financial products, which allow for payment and receipt of interest. Shariah compliant finance is therefore important for those individuals that wish to adhere to Shariah law). More than 
three-quarters of the Islamic customers have refused Shariah mortgages and instead are invested in interest-based banking.

\section{FACING CULTURAL DIVERSITY}

Many Muslim-American are still trying to bridge the breach caused by the murder of thousands and the inhumane, unjustifiable devastation of September 11, 2001. As Muslims, families are learning to straddle race and religion; (Avery) there is a growing need to publicize the diversity and positive contributions of Muslim Americans by challenging the misrepresentation and under-representation by documenting their everyday lives and contributions to the American society. (Soliman) According to Soumayya Ghannoushi of Aljazeera.net, “...years of inter-faith dialogue have done little to advance a better understanding of the Islamic faith in the western world is an indication of how profoundly entrenched in the Western psyche crude misrepresentations and vulgar stereotypes of Islam are." Sharing similar thoughts, The Aga Khan (Imam to 20 million Ismaili Muslims) states, "I refer to the superficial and misleading way in which much of the world's media treat the world of Islam." Muslims, he said, constituted a quarter of the world's people and comprised the majority population in 44 countries.

One would think these factors command a great deal of respect in American society, but unfortunately the reverse is true due to post 9/11 biases. In a statement from Muhammad Ali, "America's view of Muslims and of Islam seems to have gone from one of indifference or perhaps misunderstanding to one of hate and distrust." American Muslims do not want to be tolerated, they want to be respected. (Soliman) A national Muslim organization in Tampa, Florida offered a 30-second public service announcement to TV stations, an effort to denounce terrorism and decrease racism among the masses after the July 7, 2005 attacks in London. Central Florida's Council on American-Islamic Relations, distributed the video to local stations at the Islamic Society of Tampa Bay Area's mosque. In the video, American Muslims - a man and two women - talk about terrorists, each speaking a few words: "We reject anyone - of any faith - who commits such brutal acts and will not allow our faith to be hijacked by criminals. Islam is not about hatred and violence. It's about peace and justice.” (Echegaray)

The Islamic Society of North America (ISNA - an association of Muslim organizations and individuals in the United States and Canada that provides a common platform for presenting Islam, supporting Muslim communities, and developing educational, social and outreach programs) was among the 145 U.S. Muslim organizations and scholars who issued a fatwa (religious edict or ruling), condemning terrorism and extremism following deadly terrorist attacks this summer in London and Egypt, and insurgent assaults on civilians and coalition troops in Iraq. "The fatwa says that there is no justification in Islam for terrorism." ISNA also unveiled a brochure outlining the Islamic position against terrorism and religious extremism stating that terrorism "is the epitome of injustice because it targets innocent people."

More than 40,000 Muslims attending this year's annual ISNA convention said a special Islamic prayer, Salat el Gha'eb, (prayer for the absent) for Hurricane Katrina's victims following the weekly Friday prayer on September 2, 2005. ISNA announced that it had started a special fund to help the victims of hurricane Katrina by donating $\$ 20,000$ from its own resources and collecting over $\$ 2$ million of the $\$ 10$ million pledged by Muslim Hurricane Relief Task Force (a coordinated aid efforts for the victims of Hurricane Katrina) from mosques and congregations throughout the country, with additional contributions expected. (El-Bishlawy) "It is a national and Islamic obligation to assist one's neighbors when they are in need," said ISNA Secretary General Sayyid Syeed. "The American Muslim community pledges to do its part in helping those Americans, of all faiths, who suffered such great losses in lives and property." This overwhelming message of support by the Muslim-American community shows the deep level of compassion instilled in them from birth for citizens of all nationalities and faiths in time of need.

\section{CONCLUSION}

Muslims must do more to explain Islam to Americans, primary research to stop the constant perceived discrimination is being proposed by the researcher. By the same token, marketers need to become more educated about world cultures and accept this distinct niche as a significant and valuable retail commodity. For most Muslim groups, Islam is more than a religion, and the followers are often reluctant to change. "Muslims have to decide how 
they are going to bring these changes about, and it isn't easy. I think all Americans ...need to have a far greater understanding of the multiple complex forces of evolution that are taking place within the Islamic world". (Fuller)

The Muslim-American marketplace continues to be a cultural challenge to businesses in the United States. This ethnically diverse community offers numerous interpretations of how one should live life in a modern Western world. Complicating the understanding of each nationality are the traditions and historical values that have withstood many generations of Muslims. In order to develop an increased understanding of the impact that this target market will have throughout the United States, public and/or private educational seminars and additional media coverage must be employed.

Fostering a better understanding of Islam is not simply a challenge for Muslims, but a challenge for all Americans. Due to the free-enterprise economic system in the United States, it is believed that Muslim-Americans are more affluent and more educated than are their counterparts elsewhere in the world. This community is a nation of dedicated, hard-working, genuine, and compassionate individuals who are building the foundation for the next generation. Muslim-Americans are here to stay -their future is in America!

\section{REFERENCES}

1. Afridi. Sam. Muslims in America: Identity, Diversity, and the Challenge of Understanding. 12, November 2003. Muslim American Society, Carnegie Corporation of New York. www.carnegie.org/pdf/muslims.pdf

2. Ahmad, Imam Abu Laith Luqman. Normalizing Islam in America. 18 July 2004. Social Religious - Article Ref: IC0308-2068. www.islamicity.com/Articles/articles.asp?ref=IC0308-2068

3. Avery, Nicole Volta. Black, Muslim, and American Detroit Free Press. 30 August 2002. avery@freepress.com

4. Echegaray, Chris. Muslim Group Speaks Out Against Terror. The Tampa Tribune. 16 July 2005. http://www.tampatrib.com/MGBKGXPA7BE.html

5. El-Bishlawy, Amina. State's Hughes Thanks North American Muslims for Hurricane Fund. 2 September 2005. http://usinfo.state.gov/usinfo/Archive/2005/Sep/02-956267.html?chanlid=washfile

6. Is Islam a Religion only for Arabs? 30 May 2001. www.Islamweb.net

7. Ghannan, Jeffrey. Arab-American media grapple with attacks; Newspapers, cable TV reflect struggle between politics and patriotism Detroit Free Press. www.allied-media.com/ArabAmerican/arab\%20american\%20media\%20grapples\%20after\%20attack.htm

8. Ghannoushi, Soumayya. Western View of Islam: A Troubled History. 04 September 2005. www.Aljazeera.net

9. Kamen, Al. Brave Nuke World. Washington Post. 20, July 2005. p. A 21.

10. Kira, Hazem. More Muslim Americans Elected to Office in 2004 8, December 2005. http://www.pakistanlink.com/Commentary/2004/Dec04/03/03.htm

11. Liang, Ellen. Local Muslims, Arabs feel more vulnerable. www.allied-media.com

12. Malik, Naureen S. Free Money? One Group of Americans Can Get Interest-Free Financing -Muslims 1 July 2002.

13. Morais, Dawn. Not only Americans care about U.S. Elections. 22, October 2004. The National Catholic Reporter Publishing Company. www.natcath.org

14. Noormohamed, Nadia Abgrab. American Misperceptions: Marketing to Muslims in the United States. pp. 439+, Vol. 2(1), 2004, ISSN\# 1545-2581.

15. Parsons, Claudia. U.S. Muslim cable TV network aims to build bridges. Seattle Post-Intelligencer. 27, November 2004.

16. Fuller, Graham E. Is a Clash of Civilizations Unavoidable? A Western View in an interview with Ismail Royer. www.allied-media.com/Arab-American/clash of civilizations.htm

17. Russell, Scott. A new face in the 2005 mayor's race. Southwest Minneapolis Community Journal. 9 August 2005.

18. Shama, Sami A. Islam: The Image Question, Islamic Horizons, March-April 1418/1998, 30.

19. Sheikh, Shahid. Muslim Leadership Crisis in the Upcoming Elections. Arabic Media Internet NetworkInternews Middle East. 22, October 2004. www.amin.org 
20. Smith, Jane I. Muslim Communities: Patterns of Muslim Immigration. 12, August 2005.

http://usinfo.state.gov/products/pubs/muslimlife/immigrat.htm

21. Soliman, Ahmed. Born in the USA: Muslim-Americans.

www.solimanproductions.com/docs/ASPpresskit.pdf

22. The White House, Office of the Press Secretary. 15, October 2004. Jacksonville, Oregon. www.islamicinstitute.org

23. Yonge, David. Bridges TV will serve American Muslims. Toledo Blade. 18, December 2004. www.toledoblade.com/apps/pbcs.dll/article?AID=/20041218/NEWS10/412180319

\section{NOTES}




\section{NOTES}

